\title{
Healthy chocolate enriched with probiotics: a review
}

\author{
Md Nur HOSSAIN ${ }^{1}$, Chaminda Senaka RANADHEERA ${ }^{1}$, Zhongxiang FANG ${ }^{1}$, Said AJLOUNI ${ }^{1 *}$ (iD
}

\begin{abstract}
Benefits associated with consumption of probiotics and prebiotics are well known and many clinical studies have proven their positive impact on human health. The industrial interest in the usage of probiotics along with prebiotics in new food and pharmaceutical products is gradually increasing. However, the probiotic viability and stability during processing, storage as well as under adverse conditions during the gastrointestinal digestion are the significant challenges in probiotic products development. Chocolates are one of the most appealing products among the majority of people and may serve as a suitable carrier for probiotic delivery to the human gut. In addition, chocolate possess a wide range of potent antioxidants and other nutrients that can positively affect human health. Since there is an increasing demand for novel probiotic products, this review will examine the chocolates as a source of prebiotics, a carrier for already encapsulated probiotics and its possible industrial applications.
\end{abstract}

Keywords: chocolates; probiotics; prebiotics; microencapsulation; lactobacilli; bifidobacteria.

Practical Application: Chocolates with encapsulated probiotics could be an excellent carrier for probiotic delivery to gut.

\section{Introduction}

Probiotics are the beneficial microorganisms improving the intestinal microbial balance in the host when administrated into the gut in sufficient numbers (Ranadheera et al., 2010). The FAO/WHO and the International Scientific Association for Probiotics and Prebiotics defined probiotics as "[...] live microorganisms that, when administered in an adequate amount, confer a health benefit on the host" (Hill et al., 2014, p. 506-514). Probiotic food products have used worldwide and they are gaining an increasing popularity day by day (Sanders et al., 2018). Current trends in the consumption of probiotics are associated with increased levels of health-consciousness and the availability of probiotics in the form of dietary supplements (Chugh \& Kamal-Eldin, 2020). The probiotics estimated market value in both food and supplements was closed out the year 2017 at $\$ 45.64$ billion and forecasted to hit $\$ 78.42$ billion by the year 2025 (Probiotics Market Outlook, 2018).

The most extensively studied and used probiotics are lactic acid bacteria, mainly Lactobacillus and Bifidobacterium species. These genera are generally recognized as safe (GRAS) as there are no or minor health risk to consumers (Ranadheera et al., 2018). Similarly, many other genera such as Staphylococcus, Enterococcus (Sathyabama et al., 2014), Propionibacterium (Cousin et al., 2011), Leuconostoc (Diana et al., 2015), Bacillus (Cutting, 2011), certain yeast (Asmat et al., 2018) and some filamentous fungi (Vibhute et al., 2011) have been also utilized as probiotics over the years. Probiotics are available in various pharmaceutical and food formulations based on the different carrier matrices that are currently widely available (Ranadheera et al., 2017).

A summary of commercially available products containing probiotics and recommended for human usage is presented in Table 1. Probiotics are available in various forms including food and beverages, powders, effervescent and capsules. Dairy and non-dairy food products including soy products, cereal-based products, fruit and vegetable juices, fermented meat and fish products are some of the popular probiotic carriers (Ranadheera et al., 2018). Various formulations based on these carrier matrices are widely available in the market at present (Ranadheera et al., 2017). However, fermented dairy products such as yogurt and fermented milk are the most common and the traditional modes of delivering probiotics to humans (Mitra \& Ghosh, 2020; Lucatto et al., 2020). Delivery of probiotics through carrier food products seems more efficient due to the synergistic effect among the ecapsulants and the food carrier which can provide additioonal protection to the probiotics during gastrointestinal transit (Ranadheera et al., 2010).

Prebiotics are a type of dietary fibers and have beneficial physiological effects on the gastrointestinal microbiota (Zhang et al., 2018). The metabolites of dietary fiber formed as a result of their fermentation in the colon provide mechanistic links between fiber intake and health benefits (Roberfroid et al., 2010). The prebiotic products that cause a selective modification in the gut microbiota composition and/or activity(ies) could be induced in the colon and the extra-intestinal compartments and contribute towards reducing the risk of dysbiosis and associated intestinal and systemic pathologies (Roberfroid et al., 2010; Zucko et al., 2020). Nowadays, the synbiotic approach or combination of probiotics and prebiotics in food products is gaining a considerable attention as this process boosts the health benefits of both probiotics and prebiotics due to their synergistic nature (Ranadheera et al., 2017; Shafi et al., 2019). 
Table 1. Commercially available products containing probiotic recommended for human consumption.

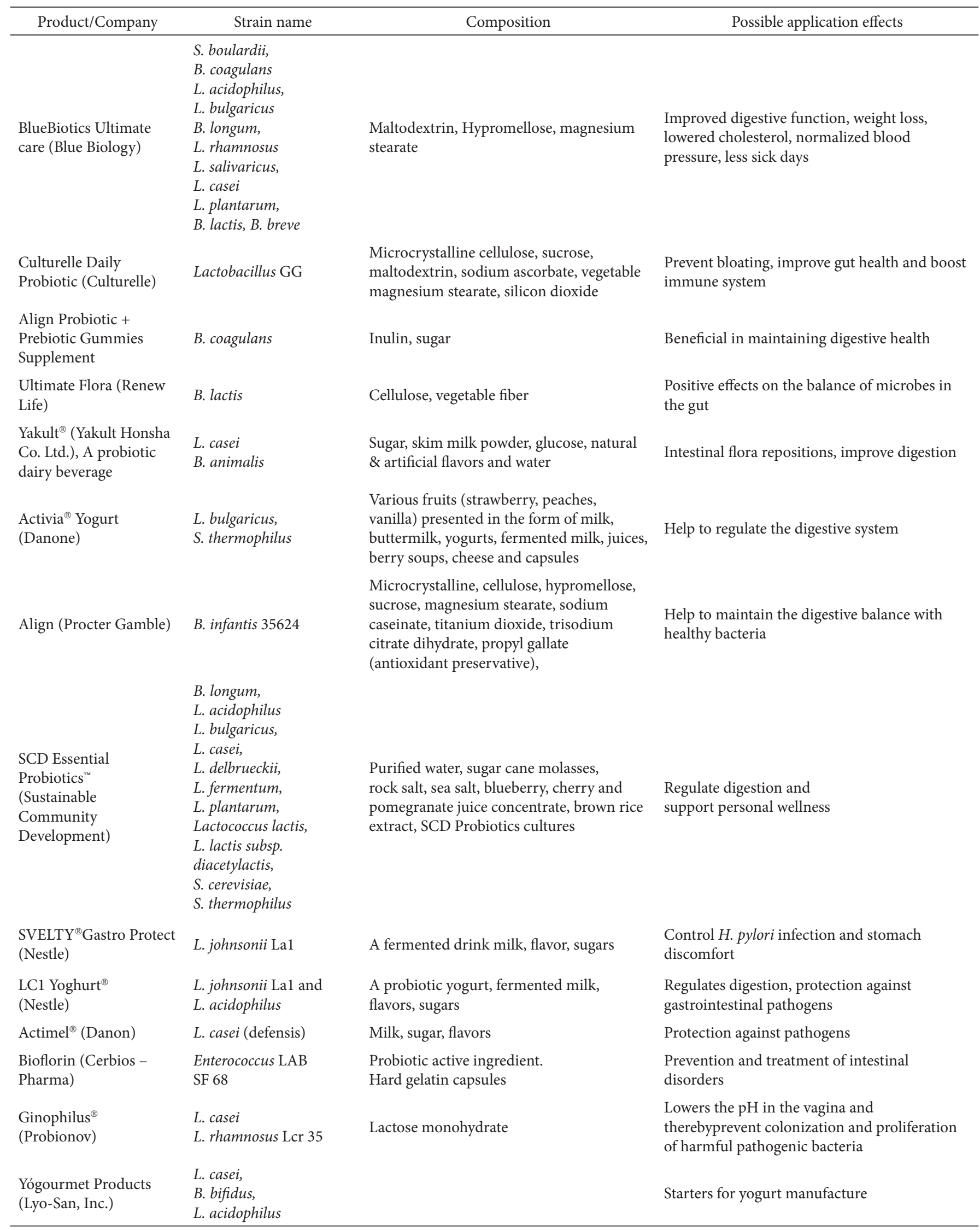


Hossain et al.

Table 1. Continued...

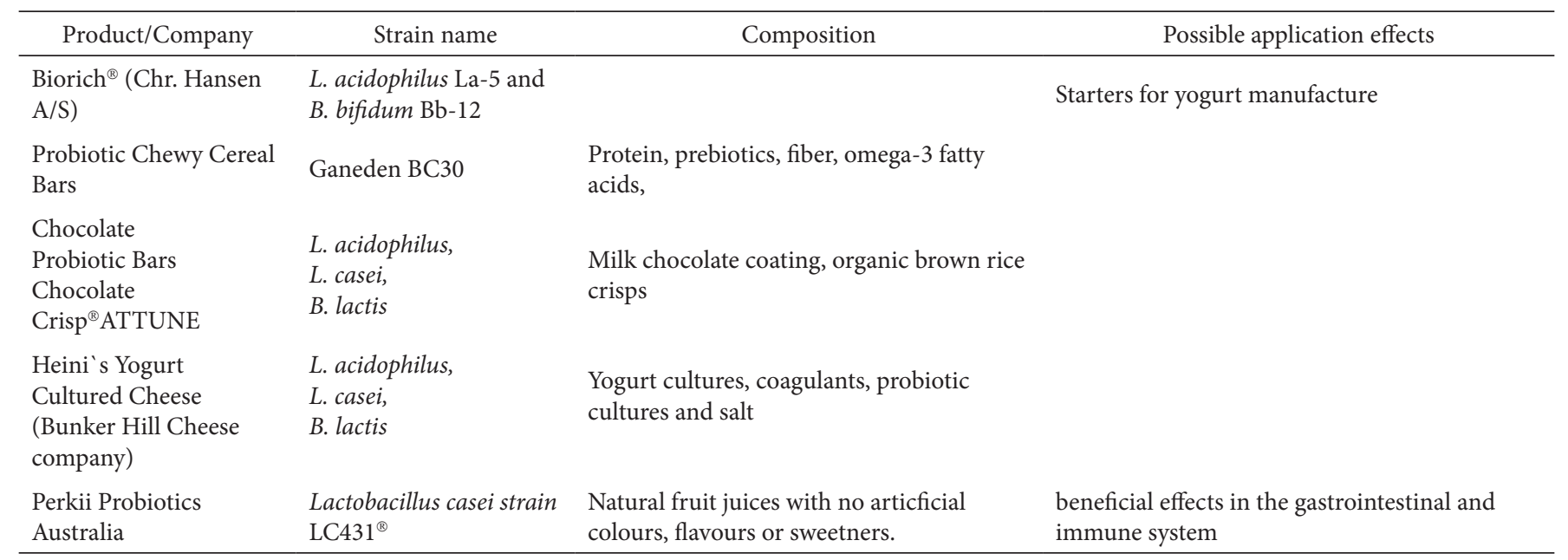

Adapted and modified from Soccol et al. (2014).

Chocolate is becoming increasingly popular as a carrier delivering probiotics to gut ( $\mathrm{Rad}$ et al., 2016). Chocolate is composed of cocoa mass and sugar suspended with cocoa butter matrix. The major types, dark, milk and white chocolate differ mainly in the content of cocoa solids, milk fat and cocoa butter (Possemiers et al., 2010). The popularity of chocolate around the world combined with high level of health-related awareness of the contemporary consumer is increasing rapidly and the idea of the enriching composition of different kinds of chocolate with probiotics has high market demand (Min et al., 2019). The popularity of chocolate seems to be mostly associated with its higher sensory acceptability and positive emotions. Chocolate satisfies a broad range of consumers; however, using chocolate as a food matrix to carry probiotics has not been thoroughly investigated (Min et al., 2019). The carrier substrates exert a significant influence on the efficacy of probiotics and regarding chocolate such information is also not thoroughly reviewed (Rad et al., 2016). This review summarizes the current evidence on chocolate-probiotic applications both in the research and industrial domains. Besides, therapeutic effects and health benefits of probiotics have also been briefly discussed. Since probiotics along with prebiotics confer additional health benefits on the host when administered together due to their synergistic effect (Gibson et al., 2017), hence an account on the effect of prebiotics on probiotics efficacy is presented. Finally, as most of the publications on novel probiotic chocolate products have been focused on encapsulation techniques (Kemsawasd et al., 2016; Mirkovic et al., 2018; Nambiar et al., 2018), a brief account on efficacy of probiotic encapsulation is also presented.

\section{Health and therapeutic effects of probiotics}

The therapeutic effects associated with regular probiotic consumption is clear and well documented in the literature (Hill et al., 2014). In order to achieve the therapeutic effects, the proposed functional dose for use as foods or supplements is $1 \times 10^{9}$ colony forming units (CFU) of probiotics per serving, and the nominated probiotics mostly include Lactobacillus acidophilus, L. casei, L. fermentum, L. gasseri, L. johnsonii, L. paracasei, L. plantarum, L. rhamnosus and L. salivarius and Bifidobacterium adolescentis, B. animalis, B. bifidum, B. breve and B. longum (Sanders \& Younes, 2018). Many research evidences suggest that probiotics create a healthy gut environment and a vigorous immune system (Bäckhed et al., 2012; Ritchie \& Romanuk, 2012). However, in order to achieve health benefits of probiotics certain requirements should be fulfilled: (1) resistance to the manufacturing process and storage stress and maintenance viability in the commercial product until the end of the shelf-life, with a threshold of $10^{8}-10^{9} \mathrm{CFU} / \mathrm{g}$ at the time of consumption (Rosa et al., 2016) and (2) persistence to the adverse physicochemical conditions in the gastrointestinal tract, such as gastric acid and bile secretions.

The survivability of probiotic bacteria actively detracts during the gastrointestinal digestion due to harsh conditions. Consequently, it has been reported that probiotics can enter into viable but non-culturable (VBNC) state when exposed to harsh, stressful conditions such as the gastrointestinal digestion (Bäckhed et al., 2012; Ritchie \& Romanuk, 2012) and this may affect the delivering of health benefits to the consumers. Consequently, it is recommended to consume probiotics several days per week (Harvard Health Publishing, 2019). Probiotics have been known for other beneficial health effects, and the consumption of probiotics alone or in food can evince antioxidant activity and reduce damages caused by oxidation (Sanders, 2015). However, the oxidation resistant ability of probiotics, especially the underlying mechanisms, is not fully understood. As oxidative stress has been linked with altered gut microbiota, the positive effects of probiotics on intestinal flora composition could be a possible mechanism in this scenario (Wang et al., 2017; Vasconcelos et al., 2019).

Similar to animals, probiotics also have their antioxidant enzymatic systems (Wang et al., 2017). Moreover, probiotics can stimulate the antioxidant system in the host and elevate the activities of antioxidants efficiently (Khaledabad et al., 2020). There are several possible functions of probiotics that include the production and secretion of antimicrobial substances, which can cause displacement of pathogen colonization in the gut (O'Shea et al., 2012; Zendeboodi et al., 2020). Additionally, the 
secretion of substances such as protein, short chain fatty acid (SCFA), organic acids, cell surface active components and DNA from probiotics can exert the same therapeutic effect as probiotics do on gastrointestinal disease. These therapeutic agents are known as pharmabiotics or probioactive (O'Shea et al., 2012). For examples, Agamennone et al. (2018) stated that antibiotic-associated diarrhea (AAD) was a side-effect frequently linked to the use of broad-spectrum antibiotics, and clinical studies showed that co-administration of specific probiotics reduced the risk for AAD.

The European Pediatric Association (EPA) summarized recommendations and credited guidelines on the use of probiotics for children with selected clinical conditions. However, particular caution is necessary for certain groups, including premature infants, immunocompromised and critically ill patients (Hojsak et al., 2018). Such caution is needed, since not enough evidence is currently available about the positive effect of probiotics in these categories of people. Additionally, probiotics have been used in the prevention and treatment of lactose intolerance (Almeida et al., 2012) and common gastrointestinal disorders (Barnes \& Yeh, 2015; Roobab et al., 2020) including irritable bowel syndrome, Crohn's disease and peptic ulcers (Weichselbaum, 2009), high blood pressure (Sirtori et al., 2015; Sarfraz et al., 2019) and serum cholesterol (Kumar et al., 2012; Grom et al., 2020). Probiotics are also known for their potential anti-carcinogenic properties (Zitvogel et al., 2017).

\section{Prebiotics and their impact on probiotics}

According to the expert consensus document of the International Scientific Society for Probiotic and Prebiotics, prebiotics are non-viable substrates that serve as nutrients for beneficial microorganisms by the host, including resident, indigenous microbes and non-resident, administrated probiotic strains (Gibson et al., 2017). In order to be highly effective, prebiotic is required to meet three basic criteria: (1) the ability to resist host gastrointestinal tract (GIT) digestion (Charbonneau et al., 2016), (2) being fermentable by intestinal microorganisms (Singla \& Chakkaravarthi, 2017) and (3) stimulating the growth and activity of some intestinal bacteria, specially probiotics. Since prebiotics support the growth and activity of probiotics and other fermentative bacteria, understanding the role and metabolism of prebiotics by the probiotic bacteria are essential for achieving the maximum health benefits associated with probiotics intake (Rastall, 2013). Prebiotics target intestinal microbiota to improve host health (Chen et al., 2013).

It has been well established that the intestinal microbiota (bifidobacteria and lactobacilli) play a crucial role in gastrointestinal development and maintaining good health. Naturally human gut contains more than 40 billion of microbes which highlights the existence of a highly complex microbiota ecosystem with the potential for profound effects on metabolism and immune function (Shreiner et al., 2015). LAB and certain yeast help in maintaining healthy microbiota balance in the human gut. The oligosaccharides especially fructooligosaccharides and galactooligosaccharides which are known as prebiotics preferentially metabolized by Bifidobacteria can be degraded by $\beta$-fructanosidase and $\beta$-galactosidase enzymes. Thus, prebiotics helps probiotics survival in a competitive environment in mixed culture ecosystems in the human gut (Cani \& Everard, 2016). The use of probiotics and prebiotics in combination or separately can change the microbiota in the host.

Many prebiotic substances are used in the food industry including inulin, a polymer of fructose with a terminal glucose, shorter chain inulin types (2-8 unites) known as fructooligosaccharides and galactooligosaccharides with of B,2-1 linkage, polydextrose, wheat dextrin, acacia gum, psyllium, banana and whole grains (Wilson \& Whelan, 2017). To date, all known prebiotics are carbohydrate compounds, primarily oligosaccharides, known to resist digestion in the human small intestine and reach the colon where the gut microbiota ferment them. Studies have reported that inulin and fructooligofructose, lactulose, and resistant starch meet all aspects of prebiotic definition, including the stimulation of Bifidobacterium (Slavin, 2013).

Galactooligosaccharides (GOS) are produced enzymatically from lactose for commercial food applications, in addition to infant formulae to mimic breast milk oligosaccharides. GOS encourage the gut bacterial population and reduce intestinal infections (Barile \& Rastall, 2013). In particular, bovine milk-derived oligosaccharides support the growth of probiotic $B$. animalis ssp. lactis and improves intestinal health (Radke et al., 2017). Chen et al. (2013) evaluated the prebiotic properties of pectic oligosaccharides (POS) using a fecal batch culture fermentation. The POS increased the number of bifidobacteria and lactobacilli and produced a higher concentration of acetic, lactic, and propionic acid than their parent pectin. POS decreased the number of Bacteroides and Clostridia while their precursor pectin increased these microbes (Vandeputte et al., 2017).

The effects of POS on the growth of probiotic bacteria and the production of short-chain fatty acids were comparable to those of the most studied prebiotic fructooligosaccharide (Wilson \& Whelan, 2017). POS modified the intestinal microbiota by stimulating the growth of species involved in immunity development, such as Bifidobacterium spp, Sutturella wadsworthia, and Clostridium cluster XIVa microorganisms, and at the same time increased the production of the short chain fatty acid, butyrate and propionate. Such short chain fatty acids are essential for leptin production, lipoprotein metabolism and anti-inflammatory activities (Shreiner et al., 2015; Tan et al., 2014).

Interventions to prevent intestinal inflammation may be achieved with fermentable prebiotic fibers that enhance beneficial bifidobacteria or with soluble fibers that block bacterial-epithelial adherence (Simpson \& Campbell, 2015). Significant evidences confirm that prebiotics increase the bioavailability of minerals and stimulate the immune system (Gibson et al., 2017). However, there is less clear evidence regarding their prophylactic or therapeutic role in gastrointestinal infections. Possible mechanisms have been proposed to investigate gut microbiota-host interactions, including the role of novel bacteria, the regulation of antimicrobial peptide production, the maintenance of the gut barrier function and innate intestinal immunity (Cani \& Everard, 2016).

Data from community-wide microbiome analysis demonstrated a broader effect of the prebiotics on the intestinal microbiota including the production of SCFA, immunity development, and increasing minerals bioavalability. The promising evidence of 
using prebiotic supplements to improve probiotics functions and gastrointestinal health has increased their popularity (Vandeputte et al., 2017; Guimarães et al., 2020). However, limited literatures related to the use of prebiotcs in chocolate are available. A study by Konar et al. (2018) reported that inulin and polydxtrose were the main prebiotics substances applied in chocolate encapsulation. Currently, various probiotics microencapsulating substances (encapsulants) such as alginate, skimmed milk powder, whey protein and hi-maize resistant-starch are invistigated in our laboratory. Additionnally, coating of probiotics with dark chocolate could be an excellent encapsulant to protect them from environmental stress conditions and for optimal delivery in the human digestion system (Campagnolo et al., 2017; Foong et al., 2013).

\section{Probiotic delivery: efficacy of encapsulation}

Although probiotics are one of the most promising ingredients to produce functional foods and nutraceuticals, their low resistance to different environmental and technological conditions in food systems is a significant drawback for their effective utilization (Sanders et al., 2018). Hence, various approaches have been proposed and microencapsulation is an excellent method to protect probiotics during processing, storage and gastrointestinal transit (Chen et al., 2017). Encapsulation is a technique which entraps an active agent into a wall material of another substance producing particles on a nano, micro or millimeter scale (Ray et al., 2016). Microencapsulation is expected to extend the shelf life of probiotics at ambient temperature in various food matrices, increase their heat resistance, improve their compression and shear stress resistance, and enhance their acid tolerance (Šipailiené \& Petraityte, 2018).

Efficient systems for protecting and controlling the release of encapsulated materials are highly valuable techniques in the fields of medicine, food, biotechnology and material sciences. A good number of lypoprotectants and cryoprotectants such as alginate, carrageenan, polysaccharides, skim milk, whey protein and maize starch has been proposed to encapsulate the probiotic cells (Haffner et al., 2016). Various microencapsulation techniques have been reported in the literature. Das et al. (2011) divided these techniques into two major groups, namely chemical and physical methods. However, the common tarnishes used in the food industry involve spray drying, solvent evaporation, supercritical fluid evaporation and air suspension (Das et al., 2011) and freeze drying (Saarela et al., 2006).

Microencapsulation of probiotic bacteria in functional foods on an industrial scale faces technological, biosafety and financial challenges, and questions linked to not only the encapsulation process but also to consumer behavior and acceptance patterns (Rokka \& Rantamäki, 2010). The in vitro gastrointestinal model showed that probiotic strains in a specific food matrix could offer superior protection for the delivery of the probiotic bacteria into the colon (Shreiner et al., 2015). To ascertain the protective effect of the whey protein concentrate, probiotic strains of L. casei LAFTI ${ }^{\circledR}$ L26, L. acidophilus $\mathrm{LAFTI}^{\circledR} \mathrm{L} 10$ or $B$. animalis were subjected to in vitro sequential conditions whereas stomach, duodenum and ileum conditions increased the viable cell count of $L$. casei and L. acidophilus; in both systems,
B. animalis suffered only slight decreases in viable cell count. Thus, whey protein concentrate appeared to protect the strains during delivery throughout the simulated gastrointestinal system (Gerez et al., 2012; Madureira et al., 2011).

The internal gelation technology with alginate and starch has been reported to be suitable for protecting Lactobacillus and more efficient than alginate only. The effect of two encapsulating polysaccharides (sodium alginate and carrageenan) on the viability of probiotic bacteria (L. acidophilus) in ice cream under simulated gastrointestinal (GIT) conditions significantly improved the cell survival of probiotics compared to free cells. However, sodium alginate microcapsules exhibited better release profile than carrageenan (Afzaal et al., 2019). Prebiotics (fructooligosaccharide, lactulose and raffinose) and chitosan along with alginate were also tested as a coating material to improve encapsulation of a probiotic and microspheres were produced to encapsulate L. gasseri and B. bifidum as probiotics prebiotic combination (Vandeputte et al., 2017). This work showed that the microencapsulation of L. gasseri and B. bifidum with alginate-chitosan coating could offer an effective delivery of viable bacterial cells to the colon and maintain their survival during simulated gastrointestinal conditions. Additionally, the combination of soy protein and carbohydrate (maltodextrin) as carrier resulted in the best survival rates of probiotics during storage.

Addition of prebiotics in the walls of probiotic microcapsules provided improved protection for the active organisms. In simulated gastrointestinal conditions, (Mokhtari et al., 2017) reported a significant $(\mathrm{P}<0.05)$ enhancement in the resistance of $L$. acidophilus when applying a layer of $S$. cerevisiae cell wall compound, which can be used as a novel coating materials in the food industry. However, the food and nutraceutical industries still confront some difficulties for scaling up the use of such encapsulants, though the laboratory-based results have been well establised (Jankovic et al., 2010). Various encapsulating materials along with targeted probiotics, processing techniques and their main functionalities are summarrized in Table 2.

\section{Chocolate as a probiotic carrier substrate}

The incorporation of probiotics, both free and encapsulated forms into chocolate and chocolate-based products as carriers (Table 3) could offer an excellent alternative to popular and major fermented dairy products containing probiotics (Ranadheera et al., 2018). Apparently, encapsulation of probiotics in chocolate seems much effective in terms of maintaining their viability. (Silva et al., 2017) reported that the survival of B. animalis subsp lactis and L. acidophilus incorporated into chocolate was very high with a viability level of $10^{8} \mathrm{CFU} / \mathrm{g}$. The survival of these probiotics was not significantly affected after 120 days of storage at $25^{\circ} \mathrm{C}$ and the in vitro gastrointestinal digestion of probiotic-chocolate did not cause any significant reduction in probiotic counts. However, the in vitro digestion of free B. animalis subsp lactis and L. acidophilus cultures reduced their counts by 1.4 and $0.7 \log \mathrm{CFU} / \mathrm{g}$, respectively. An in vitro setup was used to evaluate the protection of the probiotics during passage through the gastrointestinal tract via embedding them in dark and milk chocolate or liquid milk (Succi et al., 2017). Both chocolates 
Table 2. Effects of encapsulating materials and encapsulation techniques on probiotics functions.

\begin{tabular}{|c|c|c|c|c|}
\hline Probiotic strain/products & Encapsulating materials & $\begin{array}{l}\text { Processing } \\
\text { technique }\end{array}$ & Probiotics Function & References \\
\hline $\begin{array}{l}\text { L. rhamnosus } \\
\text { L. salivarius } \\
\text { L. plantarum } \\
\text { L. acidophilus } \\
\text { L. paracasei } \\
\text { B. longum } \\
\text { B. lactis } \mathrm{Bl} 04 \\
\text { B. lactis } \mathrm{Bl} 07 \text { HOWARU L. } \\
\text { rhamnosus HOWARU } \\
\text { B. bifidum }\end{array}$ & $\begin{array}{l}\text { Alginate, guar gum, } \\
\text { xanthan gum, locust bean } \\
\text { gum, carrageenan, vegetable } \\
\text { oil, tween } 80\end{array}$ & $\begin{array}{l}\text { Emulsion } \\
\text { combination }\end{array}$ & bile and acid tolerance & Ding \& Shah (2009) \\
\hline $\begin{array}{l}\text { L. paracasei ssp paracasei } \\
\text { F19 } \\
\text { B. lactis } \mathrm{Bb} 12\end{array}$ & $\begin{array}{l}\text { Casein, hi-maize resistance } \\
\text { starch }\end{array}$ & $\begin{array}{l}\text { Freeze drying } \\
\text { followed by } \\
\text { emulsification }\end{array}$ & $\begin{array}{l}\text { Survival after drying and } \\
\text { storage }\end{array}$ & Heidebach et al. (2010) \\
\hline L. acidophilous $\mathrm{Z} 1 \mathrm{~L}$ & Free cells & - & $\begin{array}{l}\text { Bile, acid and low } \mathrm{pH} \\
\text { tolerance }\end{array}$ & Sabir et al. (2010) \\
\hline L. plantarum 299 & $\begin{array}{l}\text { Whey protein coated with } \\
\text { alginate }\end{array}$ & Freeze drying & $\begin{array}{l}\text { Low } \mathrm{pH} \text { and high bile } \\
\text { tolerance }\end{array}$ & Gbassi et al. (2009) \\
\hline $\begin{array}{l}\text { B. bifidum } \\
\text { L. gasseri }\end{array}$ & Sodium alginate, chitosan & Freeze drying & $\begin{array}{l}\text { High viability and shelf life } \\
\text { at } 4{ }^{\circ} \mathrm{C}\end{array}$ & Chávarri et al. (2010) \\
\hline $\begin{array}{l}\text { L. paracasei ssp. Tolerance } \\
\text { L. delbrueckii ssp. bulgaricus }\end{array}$ & Skim milk, trehalose & Freeze drying & $\begin{array}{l}\text { Good survivability } \\
\text { at } 4{ }^{\circ} \mathrm{C}\end{array}$ & Jalali et al. (2012) \\
\hline L. casei NCFB 161 & $\begin{array}{l}\text { Alginate, gelatinized starch, } \\
\text { lecithin }\end{array}$ & Freeze drying & Long shelf life & Donthidi et al. (2010) \\
\hline B. lactis & $\begin{array}{l}\text { Maltodextrin, inulin, } \\
\text { oligofructose }\end{array}$ & Spray drying & High viability & Paim et al. (2016) \\
\hline L. casei 01 & $\begin{array}{l}\text { Alginate, hi-maize resistant } \\
\text { starch }\end{array}$ & $\begin{array}{l}\text { Emulsion } \\
\text { technique }\end{array}$ & $\begin{array}{l}\text { High gastrointestinal } \\
\text { tolerance }\end{array}$ & Pankasemsuk et al. (2016) \\
\hline L. bulgaricus & $\begin{array}{l}\text { Whey protein isolate, } \\
\text { alginate }\end{array}$ & Freeze drying & $\begin{array}{l}\text { High gastrointestinal } \\
\text { tolerance }\end{array}$ & Chen et al. (2017) \\
\hline L. acidophilus NCDC 016 & Maltodextrin, gum Arabic & Spray drying & Temperature tolerance & Arepally \& Goswami (2019) \\
\hline $\begin{array}{l}\text { S. succinus MabB4 } \\
\text { E. fecium FldM3 }\end{array}$ & $\begin{array}{l}\text { Sugar beet, chicory, oats } \\
\text { and } \mathrm{Na} \text {-alginate }\end{array}$ & emulsion & $\begin{array}{l}\text { High gastrointestinal } \\
\text { tolerance }\end{array}$ & Sathyabama et al. (2014) \\
\hline $\begin{array}{l}\text { B. lactis } \\
\text { L. acidophilus }\end{array}$ & Molten fat with lecithin & Spray chilling & $\begin{array}{l}\text { High gastrointestinal } \\
\text { tolerance }\end{array}$ & Lara Pedroso et al. (2012) \\
\hline $\begin{array}{l}\text { L. acidophilus } 5 \\
\text { L. casei } 01\end{array}$ & $\begin{array}{l}\text { GOS, inulin, alginate, } \\
\text { chitosan }\end{array}$ & Emulsification & High survivability at GIT & $\begin{array}{l}\text { Krasaekoopt \& Watcharapoka } \\
(2014)\end{array}$ \\
\hline B. bifidum $\mathrm{Bb} 12$ & Whey & Spray drying & Long viability & Castro-Cislaghi et al. (2012) \\
\hline $\begin{array}{l}\text { B. bifidum } \\
\text { L. acidophilus }\end{array}$ & $\begin{array}{l}\text { Cell wall of yeast } \\
\text { (S. cerevisiae) }\end{array}$ & $\begin{array}{l}\text { Calcium alginate } \\
\text { emulsion }\end{array}$ & High survivability at GIT & Mokhtari et al. (2017) \\
\hline $\begin{array}{l}\text { L. reuteri } \\
\text { Pediocucus acidilactici } \\
\text { L. salivarius }\end{array}$ & Inulin, alginate & Extrusion & $\begin{array}{l}\text { Highly effective against bile } \\
\text { and acid }\end{array}$ & Atia et al. (2016) \\
\hline L. plantarum & $\begin{array}{l}\text { Maltodextrin, wheat } \\
\text { dextrin, hi-maize }\end{array}$ & Freeze drying & Highest cell viability at GIT & Chotiko \& Sathivel (2016) \\
\hline $\begin{array}{l}\text { L. casei LAFTI L } 26 \\
\text { L. acidophilus LAFTIL10 } \\
\text { B. animalis Bo }\end{array}$ & Whey cheese matrix & Emulsion & Highest cell viability at GIT & Madureira et al. (2011) \\
\hline L. acidophilus & $\begin{array}{l}\text { Sodium alginate, } \\
\text { carrageenan }\end{array}$ & Gel bead formation & Highest cell viability & Afzaal et al. (2019) \\
\hline
\end{tabular}


Table 3. Chocolates as a carrier for probiotic delivery.

\begin{tabular}{|c|c|c|c|}
\hline Strain & Mode of probiotics & Carrier Vehicle & Reference \\
\hline $\begin{array}{l}\text { L. acidophilus LH5 } \\
\text { S. thermophilus ST3 } \\
\text { B. breve BR2 }\end{array}$ & $\begin{array}{l}\text { Protein and polysaccharide coated } \\
\text { probiotics }\end{array}$ & $\begin{array}{l}\text { Milk, semisweet and dark } \\
\text { chocolates }\end{array}$ & Lalicic-Petronijevic et al. (2017) \\
\hline $\begin{array}{l}\text { L. acidophilus La } 14 \text { ATCC SD } 5212 \\
\text { L. paracasei Lpc-32 ATCC SD } 5275\end{array}$ & Freeze dried powder & White chocolates & Konar et al. (2018) \\
\hline $\begin{array}{l}\text { L. paracasei F19 } \\
\text { L.casei DG }\end{array}$ & Non-encapsulated delivery & Dark chocolates & Succi et al. (2017) \\
\hline L. reuteri DSM17398 & & & \\
\hline $\begin{array}{l}\text { L. acidophilus LA3, } \\
\text { B. animalis subsp. lactis } \\
\text { BLC1 }\end{array}$ & Non-encapsulated delivery & Semisweet chocolate & Silva et al. (2017) \\
\hline $\begin{array}{l}\text { L. helveticus, } \\
\text { B. longum }\end{array}$ & $\begin{array}{l}\text { Microencapsulated freeze-dried } \\
\text { powder }\end{array}$ & $\begin{array}{l}\text { dark and milk chocolate or liquid } \\
\text { milk }\end{array}$ & Possemiers et al. (2010) \\
\hline $\begin{array}{l}\text { L. acidophilus } \\
\text { B. lactis }\end{array}$ & Freeze dried powder & Milk and dark chocolates & Lalicic-Petronijevic et al. (2015) \\
\hline L. brevis ssp. Coagulans & Freeze dried labre powder & Milk chocolates & Yonejima et al. (2015) \\
\hline $\begin{array}{l}\text { L. rhamnosus } \\
\text { B. longum }\end{array}$ & $\begin{array}{l}\text { Non-encapsulated freeze dried and } \\
\text { / encapsulated spray dried powder }\end{array}$ & Dark chocolates & Champagne et al. (2015) \\
\hline Bacillus indicus & $\begin{array}{l}\text { Freeze dried powder with } \\
\text { maltodextrin and lemon fiber }\end{array}$ & Dark chocolates & Erdem et al. (2014) \\
\hline $\begin{array}{l}\text { L. acidophilus NCFM } \\
\text { B. lactis HN019 }\end{array}$ & Freeze dried powder & Chocolates & Klindt-Toldam et al. (2016) \\
\hline L. plantarum & Non-encapsulated delivery & Dark chocolates & Foong et al. (2013) \\
\hline
\end{tabular}

offered superior protection which was $91 \%$ and $80 \%$ survival in milk chocolate for L. helveticus and B. longum, respectively compared to $20 \%$ and $31 \%$ found in milk (Possemiers et al., 2010). Unsimilarly, a study by Gadhiya et al. (2018) reported that chocolate enriched with $L$. helveticus MTCC 5463 freeze dried culture $(3 \% \mathrm{w} / \mathrm{w})$ yielded acceptable organoleptic qualities, but the probiotics viability was maintained at $2.42 \times 10^{8} \mathrm{CFU}$ g-1 only for 15 days when of storage at $10 \pm 2{ }^{\circ} \mathrm{C}$.

The synbiotic chocolate mousse supplemented with L. paracasei subsp. paracasei LBC 82 showed excellent delivery of $L$. paracasei, and the prebiotic inulin did not interfere with its viability or sensory preferences (Gadhiya et al., 2018).

Furthermore, the fortification of chocolate with microencapsulated probiotics B. longum resulted in improved stability and viability (Champagne et al., 2015). The fortification of confectionery with probiotics is rather tricky since some processing steps are conducted at high temperatures and these products are usually stored at ambient temperature. However, modifying chocolate manufacturing process and protecting the probiotic from the steps involved in heat treatments could be an effective method for making probiotics to be delivered to the gut environment in a viable condition and adequate numbers for host health (Yonejima et al., 2015).

Another strategy to overcome this problem would be the selection of suitable probiotic strains. For example, L. plantarum-LRCC5193 (LP-LRCC5193) isolated from Kimchi, a fermented vegetables demonstrated a significantly higher degree of heat, acid, and bile acid tolerance compared to other lactic acid bacteria (Lim et al., 2018). The lyophilized LP-LRCC5193 in chocolate maintained 92.9 log percentage and 97.2 log percentage survival rate when exposed to stomach juice 
( $\mathrm{pH} 2.5$, pepsin $0.04 \%$ ) and intestinal juice (oxgall 0.5\%, trypsin $0.04 \%$, and pancreatin $0.04 \%$ ) respectively.

A compilation of three probiotic strains (B. breve BR2, L. acidophilus LH5 and S. thermophilus ST3) microencapsulated with lypoprotectants and incorporated in milk, semisweet and dark chocolates as carriers maintained high probiotic viability (8-9 log CFU/g) during 360 days of storage at $4{ }^{\circ} \mathrm{C}$ and $20{ }^{\circ} \mathrm{C}$ (Lalicic-Petronijevic et al., 2017). Thus, milk, dark and semisweet chocolate products would be excellent vehicles to deliver probiotics because of the high viability of probiotics during the shelf-life of foods (Erdem et al., 2014). In fact, probiotic dark chocolate has higher potential in new product development in the functional food market (Possemiers et al., 2010).

Chocolate is rich in natural antioxidants and its nutritional quality can be enhanced by the incorporation of probiotics and/or prebiotics (Gadhiya et al., 2015). Cocoa and dark chocolate have a wide range of potent antioxidants and other nutrients that can positively affect human health. Notably, dark chocolate is widely recognized as a source of various bioactive compounds, such as flavonoids and phenolic acids, which possess high antioxidant activities (Foong et al., 2013). The antioxidant compounds in chocolate can be serve as a better probiotic carrier than popular dairy products for intestinal delivery (Possemiers et al., 2010). Consequently, the coating of probiotics in dark chocolate could be an excellent solution to protect them from environmental stress conditions and for optimal delivery into the human digestive system (Foong et al., 2013).

\section{Probiotic chocolates: challenges in the industrial applications}

Chocolates are the most appealing food among the consumers produced from cocoa liquor. Considering the demand, the food industries are setting their production goals per year (Sanders et al., 2018). For the commercialization and scale-up the cost-effective production is one of the critical parameters to be taken into consideration and the prices of the raw materials and technologies as well as health and environmental safety procedures are becoming more and more challenging (Rokka \& Rantamäki, 2010). However, recent developments in the food industry showed that chocolate products containing encapsulated probiotics is gaining a higher market share (Haffner et al., 2016).

Though there is no clear dietary recommendation on chocolate consumption, 13-15g per day of probiotic dark chocolate has been suggested to be sufficient to ensure the balance of the intestinal microflora and antioxidants requirements (Petyaev \& Bashmakov, 2017; Succi et al., 2017). Lactobacillus and Bifidobacterium are the widely used probiotic bacteria for probiotic chocolate products at present however, there is a significant potential in incorporating other species (Sanders \& Younes, 2018). Dark, semi-sweet and white chocolates can be used as probiotic carriers at the industrial level, and FOS like fructan, galactan, inulin, pectin can be added as prebiotics which enhances the functionality of these probiotic products. The primary challenges for probiotic chocolate similar to other probiotic carrier food products are difficulties in maintaining their viability until time of consumption (Gadhiya et al., 2015) and processing conditions like high temperature.

Consequently, as mentioned previously (section 5) modifying chocolate manufacturing process and protecting the probiotic during the various steps of chocolate manufacturing, including heat treatments, could be an effective method for making probiotics to be delivered to the gut environment in a viable condition and adequate numbers for host health. Additionally, providing protection to probiotic strains via encapsulation before addition to food carriers and manufacturing the final products are very essential. As free probiotic bacteria are not able to survive for a long time in an adverse environment, encapsulation with lypoprotectants or cryoprotectants could be industrially reliable techniques for the development of probiotic chocolate products with an extended shelf life (Haffner et al., 2016).

Chocolate has an appealing acceptance for its color, flavor, taste, mouthfeel and texture and at the industrial scale of production, incorporation of probiotics into chocolates must not alter these positive attributes (Sandoval-Castilla et al., 2010). For example, the particle size is an essential factor which directly affects the textural properties of chocolates (Sandoval-Castilla et al., 2010) and incorporation of probiotics should not interfere with these aspects in the final product. Currently, the commercially available encapsulated probiotic products (pharmaceutical probiotics) are expensive and limited to those individuals who can afford to pay such a high cost. Probiotics enriched chocolate could a cheaper alternative.

However, challenges like microcapsules formation, consumer preference and application to industry should be taken into account for novel healthy product development (Jankovic et al., 2010). Other major challenges for industrial application of probiotics in chocolates are the encapsulation technology and the encapsulating materials which are expensive. Current market trends estimate that the price of encapsulated probiotic bacteria maybe two or three times that of non-encapsulated probiotics (Agheyisi, 2018). Hence, innovations and novel cost-effective technologies and materials for the massive commercialization of probiotic chocolate products are needed. The costly ingredients and non-food grade label of some of the components in culture media limit its use in the food industry.

Thus, alternative and also vegetable-based edible media which can produce same colony density or even better than the commonly used probiotic culture agar medium (DeMan Rogosa Sharpe) should be investigated at the industrial level. Additionally, consumer health issues and environmental consciousness deserve special attention in the design of future carrier matrices and technologies (Ranadheera et al., 2010). Techniques for encapsulation are developing, and new industrial-scale methods are being made available. Nevertheless, further researches are needed to optimize the use of encapsulated probiotic cells in various food systems including chocolate while considering numerous factors such as nutritional aspects, safety and ecological processing conditions at the industrial level (Haffner et al., 2016). 


\section{Conclusion}

The enormous amount of research activities at present on the beneficial impact of the gut microbiome on humans lead to the development of novel food products that directly supports the gut health. Probiotic and prebiotic formulation with chocolates is a relatively new area which has not been fully explored, and extensive research is needed to verify the therapeutic effects of probiotic chocolate products. Novel prebiotics and their effect on gut microbiota, rheological, textural, sensory and nutritional profile of probiotic chocolate products are needed to be investigated to attract health-conscious consumers for these products.

In addition, more focus should be given to cost-effective probiotic chocolate production technologies and materials as these are the driving forces in commercializing probiotic products. Microencapsulation has already been proven as one of the efficient methods for maintaining high survivability and stability of probiotic bacteria since it protects probiotics both during food processing and storage as well as under the adverse gastrointestinal conditions. Polysaccharides such as starches and alginate, gelatin and milk proteins are usually used as matrixes in probiotic microencapsulation. Some of these materials possess prebiotic properties and can enhance probiotic efficacy when encapsulated with probiotics due to synergistic effect. Besides, chocolate food matrix also possesses certain prebiotic effects.

Further, chocolate matrix can help to maintain viability during gastrointestinal transit. Hence, chocolate can be considered as a suitable vehicle in delivering probiotics and a good alternative to major popular probiotic food products. Lactobacilli and bifidobacteria are the most commonly used probiotics in manufacturing probiotic chocolate products at present, however there is a significant potential in incorporating other probiotic species. As the benefits of probiotics are now well documented, the consumers' demand for food, beverages and supplement products enriched with probiotics will continue to increase. Consequently, novel products such as chocolate-based probiotic food products would play a significant role in the future probiotic market.

\section{Acknowledgements}

Authors wish to acknowledge the Bangabandhu Science and Technology Fellowship Trust, Ministry of Science and Technology, People's Republic of Bangladesh for financial support to Md Nur Hossain for his $\mathrm{PhD}$ studies.

\section{References}

Afzaal, M., Saeed, F., Arshad, M. U., Nadeem, M. T., Saeed, M., \& Tufail, T. (2019). The effect of encapsulation on the stability of probiotic bacteria in ice cream and simulated gastrointestinal conditions. Probiotics and Antimicrobial Proteins, 11(4), 1348-1354. http:// dx.doi.org/10.1007/s12602-018-9485-9. PMid:30426464.

Agamennone, V., Krul, C. A. M., Rijkers, G., \& Kort, R. (2018). A practical guide for probiotics applied to the case of antibiotic-associated diarrhea in The Netherlands. BMC Gastroenterology, 18(1), 103. http://dx.doi.org/10.1186/s12876-018-0831-x. PMid:30078376.
Agheyisi, R. (2018). The probiotics market: Ingredients, supplements, foods (Report code: FOD035F). Wellesley, MA: BCC Research.

Almeida, C. C., Lorena, S. L. S., Pavan, C. R., Akasaka, H. M. I., \& Mesquita, M. A. (2012). Beneficial effects of long-term consumption of a probiotic combination of Lactobacillus casei Shirota and Bifidobacterium breve Yakult may persist after suspension of therapy in lactose-intolerant patients. Nutrition in Clinical Practice, 27(2), 247251. http://dx.doi.org/10.1177/0884533612440289. PMid:22402407.

Arepally, D., \& Goswami, T. K. (2019). Effect of inlet air temperature and gum Arabic concentration on encapsulation of probiotics by spray drying. Lebensmittel-Wissenschaft + Technologie, 99, 583-593. http://dx.doi.org/10.1016/j.lwt.2018.10.022.

Asmat, S., Shaukat, F., Asmat, R., Bakhat, H., \& Asmat, T. M. (2018). Clinical efficacy comparison of Saccharomyces boulardii and lactic acid as probiotics in acute pediatric diarrhea. Journal of the College of Physicians and Surgeons--Pakistan, 28(3), 214-217. http://dx.doi. org/10.29271/jcpsp.2018.03.214. PMid:29544579.

Atia, A., Gomaa, A., Fliss, I., Beyssac, E., Garrait, G., \& Subirade, M. (2016). A prebiotic matrix for encapsulation of probiotics: physicochemical and microbiological study. Journal of Microencapsulation, 33(1), 89-101. http://dx.doi.org/10.3109/02652048.2015.1134688. PMid:26805512.

Bäckhed, F., Fraser, C. M., Ringel, Y., Sanders, M. E., Sartor, R. B., Sherman, P. M., Versalovic, J., Young, V., \& Finlay, B. B. (2012). Defining a healthy human gut microbiome: current concepts, future directions, and clinical applications. Cell Host \& Microbe, 12(5), 611622. http://dx.doi.org/10.1016/j.chom.2012.10.012. PMid:23159051.

Barile, D., \& Rastall, R. A. (2013). Human milk and related oligosaccharides as prebiotics. Current Opinion in Biotechnology, 24(2), 214-219. http://dx.doi.org/10.1016/j.copbio.2013.01.008. PMid:23434179.

Barnes, D., \& Yeh, A. M. (2015). Bugs and guts: practical applications of probiotics for gastrointestinal disorders in children. Nutrition in Clinical Practice, 30(6), 747-759. http://dx.doi.org/10.1177/0884533615610081. PMid:26538058.

Campagnolo, N., Johnston, S., Collatz, A., Staines, D., \& Marshall-Gradisnik, S. (2017). Dietary and nutrition interventions for the therapeutic treatment of chronic fatigue syndrome/myalgic encephalomyelitis: a systematic review. Journal of Human Nutrition and Dietetics, 30(3), 247-259. http://dx.doi.org/10.1111/jhn.12435. PMid:28111818.

Cani, P. D., \& Everard, A. (2016). Talking microbes: When gut bacteria interact with diet and host organs. Molecular Nutrition \& Food Research, 60(1), 58-66. http://dx.doi.org/10.1002/mnfr.201500406. PMid:26178924.

Castro-Cislaghi, F. P., Silva, C. D. R. E., Fritzen-Freire, C. B., Lorenz, J. G., \& Sant'Anna, E. S. (2012). Bifidobacterium Bb-12 microencapsulated by spray drying with whey: survival under simulated gastrointestinal conditions, tolerance to $\mathrm{NaCl}$, and viability during storage. Journal of Food Engineering, 113(2), 186-193. http://dx.doi.org/10.1016/j. jfoodeng.2012.06.006.

Champagne, C. P., Raymond, Y., Guertin, N., \& Belanger, G. (2015). Effects of storage conditions, microencapsulation and inclusion in chocolate particles on the stability of probiotic bacteria in ice cream. International Dairy Journal, 47, 109-117. http://dx.doi.org/10.1016/j. idairyj.2015.03.003.

Charbonneau, M. R., O’Donnell, D., Blanton, L. V., Totten, S. M., Davis, J. C., Barratt, M. J., Cheng, J., Guruge, J., Talcott, M., Bain, J. R., Muehlbauer, M. J., Ilkayeva, O., Wu, C., Struckmeyer, T., Barile, D., Mangani, C., Jorgensen, J., Fan, Y. M., Maleta, K., Dewey, K. G., Ashorn, P., Newgard, C. B., Lebrilla, C., Mills, D. A., \& Gordon, J. I. (2016). Sialylated milk oligosaccharides promote microbiotadependent growth in models of infant undernutrition. Cell, 164(5), 859-871. http://dx.doi.org/10.1016/j.cell.2016.01.024. PMid:26898329. 
Chávarri, M., Marañón, I., Ares, R., Ibáñez, F. C., Marzo, F., \& del Carmen Villarán, M. (2010). Microencapsulation of a probiotic and prebiotic in alginate-chitosan capsules improves survival in simulated gastro-intestinal conditions. International Journal of Food Microbiology, 142(1-2), 185-189. http://dx.doi.org/10.1016/j. ijfoodmicro.2010.06.022. PMid:20659775.

Chen, H.-Y., Li, X.-Y., Liu, B.-J., \& Meng, X.-H. (2017). Microencapsulation of Lactobacillus bulgaricus and survival assays under simulated gastrointestinal conditions. Journal of Functional Foods, 29, 248-255. http://dx.doi.org/10.1016/j.jff.2016.12.015.

Chen, J., Liang, R. H., Liu, W., Li, T., Liu, C. M., Wu, S. S., \& Wang, Z. J. (2013). Pectic-oligosaccharides prepared by dynamic highpressure microfluidization and their in vitro fermentation properties. Carbohydrate Polymers, 91(1), 175-182. http://dx.doi.org/10.1016/j. carbpol.2012.08.021. PMid:23044120.

Chotiko, A., \& Sathivel, S. (2016). Three protective agents for pectinrice bran capsules for encapsulating Lactobacillus plantarum. Food Bioscience, 16, 56-65. http://dx.doi.org/10.1016/j.fbio.2016.10.001.

Chugh, B., \& Kamal-Eldin, A. (2020). Bioactive compounds produced by probiotics in food products. Current Opinion in Food Science, 32, 76-82. http://dx.doi.org/10.1016/j.cofs.2020.02.003.

Cousin, F. J., Mater, D. D., Foligné, B., \& Jan, G. (2011). Dairy propionibacteria as human probiotics: a review of recent evidence. Dairy Science \& Technology, 9, 1-26. http://dx.doi.org/10.1051/ dst/2010032.

Cutting, S. M. (2011). Bacillus probiotics. Food Microbiology, 28(2), 214-220. http://dx.doi.org/10.1016/j.fm.2010.03.007. PMid:21315976.

Das, S. K., David, S. R. N., Raiabalaya, R., Mukhopadhyay, H. K., Halder, T., Palanisamy, M., Khanom, J., \& Nanda, A. (2011). Microencapsulation techniques and its practice. International Journal of Pharmaceutics Science and Technology, 6, 1-23.

Diana, C. R., Humberto, H. S., \& Jorge, Y. F. (2015). Probiotic properties of Leuconostoc mesenteroides isolated from aguamiel of Agave salmiana. Probiotics and Antimicrobial Proteins, 7(2), 107-117. http://dx.doi. org/10.1007/s12602-015-9187-5. PMid:25690572.

Ding, W. K., \& Shah, N. P. (2009). An improved method of microencapsulation of probiotic bacteria for their stability in acidic and bile conditions during storage. Journal of Food Science, 74(2), M53-M61. http://dx.doi.org/10.1111/j.1750-3841.2008.01030.x. PMid:19323758.

Donthidi, A. R., Tester, R. F., \& Aidoo, K. E. (2010). Effect of lecithin and starch on alginate-encapsulated probiotic bacteria. Journal of Microencapsulation, 27(1), 67-77. http://dx.doi. org/10.3109/02652040902982183. PMid:19545220.

Erdem, Ö., Gültekin-Özgüven, M., Berktaş, I., Erşan, S., Tuna, H. E., Karadağ, A., Ozcelik, B., Gunes, G., \& Cutting, S. M. (2014). Development of a novel synbiotic dark chocolate enriched with Bacillus indicus HU36, maltodextrin and lemon fiber: Optimization by response surface methodology. Lebensmittel-Wissenschaft + Technologie, 56(1), 187-193. http://dx.doi.org/10.1016/j. lwt.2013.10.020.

Foong, Y. J., Lee, S. T., Ramli, N., Tan, Y. N., \& Ayob, M. K. (2013). Incorporation of potential probiotic Lactobacillus plantarum isolated from fermented cocoa beans into dark chocolate: bacterial viability and physicochemical properties analysis. Journal of Food Quality, 36(3), 164-171. http://dx.doi.org/10.1111/jfq.12028.

Gadhiya, D., Patel, A., \& Prajapati, J. B. (2015). Current trend and future prospective of functional probiotic milk chocolates and related products: a review. Czech Journal of Food Sciences, 33(4), 295-301. http://dx.doi.org/10.17221/676/2014-CJFS.
Gadhiya, D., Shah, N. P., Patel, A. R., \& Prajapati, J. B. (2018). Preparation and shelf life study of probiotic chocolate manufactured using Lactobacillus Helveticus MTCC 5463. Acta Alimentaria, 47(3), 350358. http://dx.doi.org/10.1556/066.2018.47.3.11.

Gbassi, G. K., Vandamme, T., Ennahar, S., \& Marchioni, E. (2009). Microencapsulation of Lactobacillus plantarum spp in an alginate matrix coated with whey proteins. International Journal of Food Microbiology, 129(1), 103-105. http://dx.doi.org/10.1016/j. ijfoodmicro.2008.11.012. PMid:19059666.

Gerez, C. L., Font de Valdez, G., Gigante, M. L., \& Grosso, C. (2012). Whey protein coating bead improves the survival of the probiotic Lactobacillus rhamnosus CRL 1505 to low $\mathrm{pH}$. Letters in Applied Microbiology, 54(6), 552-556. http://dx.doi.org/10.1111/j.1472765X.2012.03247.x. PMid:22448978.

Gibson, G. R., Hutkins, R., Sanders, M. E., Prescott, S. L., Reimer, R. A., Salminen, S. J., Scott, K., Stanton, C., Swanson, K. S., Cani, P. D., Verbeke, K., \& Reid, G. (2017). Expert consensus document: the International Scientific Association for Probiotics and Prebiotics (ISAPP) consensus statement on the definition and scope of prebiotics. Nature Reviews. Gastroenterology \& Hepatology, 14(8), 491-502. http://dx.doi.org/10.1038/nrgastro.2017.75. PMid:28611480.

Grom, L. C., Rocha, R. S., Balthazar, C. F., Guimarães, J. T., Coutinho, N. M., Barros, C. P., Pimentel, T. C., Venâncio, E. L., Collopy, I., Jr., Maciel, P. M. C., Silva, P. H. F., Granato, D., Freitas, M. Q., Esmerino, E. A., Silva, M. C., \& Cruz, A. G. (2020). Postprandial glycemia in healthy subjects: Which probiotic dairy food is more adequate? Journal of Dairy Science, 103(2), 1110-1119. http://dx.doi. org/10.3168/jds.2019-17401. PMid:31785881.

Guimarães, J. T., Balthazar, C. F., Silva, R., Rocha, R. S., Graça, J. S., Esmerino, E. A., Silva, M. C., Sant’Ana, A. S., Duarte, M. C. K. H., Freitas, M. Q., \& Cruz, A. G.. (2020). Impact of probiotics and prebiotics on food texture. Current Opinion in Food Science, 33, 38-44. http://dx.doi.org/10.1016/j.cofs.2019.12.002.

Haffner, F. B., Diab, R., \& Pasc, A. (2016). Encapsulation of probiotics: insights into academic and industrial approaches. AIMS Materials Science, 3(1), 114-136. http://dx.doi.org/10.3934/matersci.2016.1.114.

Harvard Health Publishing, Harvard Medical School. (2019). Benefit of probiotics: should you take a daily dose of bacteria? Retrieved from https://www.health.harvard.edu/press_releases/benefit_of_ probiotics_should_you_take_a daily_dose_of_bacteria

Heidebach, T., Först, P., \& Kulozik, U. (2010). Influence of casein-based microencapsulation on freeze-drying and storage of probiotic cells. Journal of Food Engineering, 9(3), 309-316. http://dx.doi.org/10.1016/j. jfoodeng.2010.01.003.

Hill, C., Guarner, F., Reid, G., Gibson, G. R., Merenstein, D. J., Pot, B., Morelli, L., Canani, R. B., Flint, H. J., Salminen, S., Calder, P. C., \& Sanders, M. E. (2014). Expert consensus document. The International Scientific Association for Probiotics and Prebiotics consensus statement on the scope and appropriate use of the term probiotic. Nature Reviews. Gastroenterology \& Hepatology, 11(8), 506-514. http://dx.doi.org/10.1038/nrgastro.2014.66. PMid:24912386.

Hojsak, I., Fabiano, V., Pop, T. L., Goulet, O., Zuccotti, G. V., Çokuğraş, F. C., Pettoello-Mantovani, M., \& Kolaček, S. (2018). Guidance on the use of probiotics in clinical practice in children with selected clinical conditions and in specific vulnerable groups. Acta Paediatrica, 107(6), 927-937. http://dx.doi.org/10.1111/apa.14270. PMid:29446865.

Jalali, M., Abedi, D., Varshosaz, J., Najjarzadeh, M., Mirlohi, M., \& Tavakoli, N. (2012). Stability evaluation of freeze-dried Lactobacillus paracasei subsp. tolerance and Lactobacillus delbrueckii subsp. bulgaricus in oral capsules. Research in Pharmaceutical Sciences, 7(1), 31-36. PMid:23181077. 
Jankovic, I., Sybesma, W., Phothirath, P., Ananta, E., \& Mercenier, A. (2010). Application of probiotics in food products: challenges and new approaches. Current Opinion in Biotechnology, 21(2), 175-181. http://dx.doi.org/10.1016/j.copbio.2010.03.009. PMid:20417089.

Kemsawasd, V., Chaikham, P., \& Rattanasena, P. (2016). Survival of immobilized probiotics in chocolate during storage and with an in vitro gastrointestinal model. Food Bioscience, 16, 37-43. http:// dx.doi.org/10.1016/j.fbio.2016.09.001.

Khaledabad, M. A., Ghasempour, Z., Kia, E. M., Bari, M. R., \& Zarrin, R. (2020). Probiotic yoghurt functionalised with microalgae and Zedo gum: chemical, microbiological, rheological and sensory characteristics. International Journal of Dairy Technology, 73(1), 67-75. http://dx.doi.org/10.1111/1471-0307.12625.

Klindt-Toldam, S., Larsen, S. K., Saaby, L., Olsen, L. R., Svenstrup, G., Müllertz, A., Knochel, S., Heimdal, H., Nielsen, D. S., \& Zielińska, D. (2016). Survival of Lactobacillus acidophilus NCFM ${ }^{\circledR}$ and Bifidobacterium lactis HN019 encapsulated in chocolate during in vitro simulated passage of the upper gastrointestinal tract. Lebensmittel-Wissenschaft + Technologie, 74, 404-410. http://dx.doi. org/10.1016/j.lwt.2016.07.053.

Konar, N., Palabiyik, I., Toker, O. S., Polat, D. G., Kelleci, E., Pirouzian, H. R., Akcicek, A., \& Sagdic, O. (2018). Conventional and sugar-free probiotic white chocolate: effect of inulin DP on various quality properties and viability of probiotics. Journal of Functional Foods, 43, 206-213. http://dx.doi.org/10.1016/j.jff.2018.02.016.

Krasaekoopt, W., \& Watcharapoka, S. (2014). Effect of addition of inulin and galactooligosaccharide on the survival of microencapsulated probiotics in alginate beads coated with chitosan in simulated digestive system, yogurt and fruit juice. Lebensmittel-Wissenschaft + Technologie, 57(2), 761-766. http://dx.doi.org/10.1016/j. lwt.2014.01.037.

Kumar, M., Nagpal, R., Kumar, R., Hemalatha, R., Verma, V., Kumar, A., Chakraborty, C., Singh, B., Marotta, F., Jain, S., \& Yadav, H. (2012). Cholesterol-lowering probiotics as potential biotherapeutics for metabolic diseases. Experimental Diabetes Research, 2012, 902917. http://dx.doi.org/10.1155/2012/902917. PMid:22611376.

Lalicic-Petronijevic, J., Popov-Raljic, J., Lazic, V., Pezo, L., \& Nedovic, V. (2017). Synergistic effect of three encapsulated strains of probiotic bacteria on quality parameters of chocolates with different composition. Journal of Functional Foods, 38, 329-337. http://dx.doi. org/10.1016/j.jff.2017.09.041.

Lalicic-Petronijevic, J., Popov-Raljic, J., Obradovic, D., Radulovic, Z., Paunovic, D., Petrusic, M., \& Pezo, L. (2015). Viability of probiotic strains Lactobacillus acidophilus NCFM (R) and Bifidobacterium lactis HN019 and their impact on sensory and theological properties of milk and dark chocolates during storage for 180 days. Journal of Functional Foods, 15, 541-550. http://dx.doi.org/10.1016/j. jff.2015.03.046.

Lara Pedroso, D., Thomazini, M., Heinemann, R. J. B., \& FavaroTrindade, C. S. (2012). Protection of Bifidobacterium lactis and Lactobacillus acidophilus by microencapsulation using spraychilling. International Dairy Journal, 26(2), 127-132. http://dx.doi. org/10.1016/j.idairyj.2012.04.008.

Lim, J. H., Yoon, S. M., Tan, P. L., Yang, S., Kim, S. H., \& Park, H. J. (2018). Probiotic properties of Lactobacillus Plantarum LRCC5193, a plant-origin lactic acid bacterium isolated from kimchi and its use in chocolates. Journal of Food Science, 33(11), 2802-2811. http://dx.doi.org/10.1111/1750-3841.14364. PMid:30325520.
Lucatto, J. N., Silva-Buzanello, R. A., Mendonça, S. N. T. G., Lazarotto, T. C., Sanchez, J. L., Bona, E., \& Drunkler, D. A. (2020). Performance of different microbial cultures in potentially probiotic and prebiotic yoghurts from cow and goat milks. International Journal of Dairy Technology, 73(1), 144-156. http://dx.doi.org/10.1111/1471-0307.12655.

Madureira, A. R., Amorim, M., Gomes, A. M., Pintado, M. E., \& Malcata, F. X. (2011). Protective effect of whey cheese matrix on probiotic strains exposed to simulated gastrointestinal conditions. Food Research International, 44(1), 465-470. http://dx.doi.org/10.1016/j. foodres.2010.09.010.

Min, M., Bunt, C. R., Mason, S. L., \& Hussain, M. A. (2019). Non-dairy probiotic food products: an emerging group of functional foods. Critical Reviews in Food Science and Nutrition, 59(16), 1-16. http:// dx.doi.org/10.1080/10408398.2018.1462760. PMid:29630845.

Mirkovic, M., Seratlic, S., Kilcawley, K., Mannion, D., Mirkovic, N., \& Radulovic, Z. (2018). The sensory quality and volatile profile of dark chocolate enriched with encapsulated probiotic Lactobacillus plantarum bacteria. Sensors, 18(8), 8. http://dx.doi.org/10.3390/ s18082570. PMid:30082608.

Mitra, S., \& Ghosh, B. C. (2020). Quality characteristics of kefir as a carrier for probiotic Lactobacillus rhamnosus GG. International Journal of Dairy Technology, 73(2), 384-391. http://dx.doi.org/10.1111/14710307.12664 .

Mokhtari, S., Jafari, S. M., Khomeiri, M., Maghsoudlou, Y., \& Ghorbani, M. (2017). The cell wall compound of Saccharomyces cerevisiae as a novel wall material for encapsulation of probiotics. Food Research International, 96, 19-26. http://dx.doi.org/10.1016/j.foodres.2017.03.014. PMid:28528098.

Nambiar, R. B., Sellamuthu, P. S., \& Perumal, A. B. (2018). Development of milk chocolate supplemented with microencapsulated Lactobacillus plantarum HM47 and to determine the safety in a Swiss albino mice model. Food Control, 94, 300-306. http://dx.doi.org/10.1016/j. foodcont.2018.07.024.

O’Shea, E. F., Cotter, P. D., Stanton, C., Ross, R. P., \& Hill, C. (2012). Production of bioactive substances by intestinal bacteria as a basis for explaining probiotic mechanisms: bacteriocins and conjugated linoleic acid. International Journal of Food Microbiology, 152(3), 189-205. http://dx.doi.org/10.1016/j.ijfoodmicro.2011.05.025. PMid:21742394.

Paim, D. R. S. F., Costa, S. D. O., Walter, E. H. M., \& Tonon, R. V. (2016). Microencapsulation of probiotic jussara (Euterpe edulis M.) juice by spray drying. Lebensmittel-Wissenschaft + Technologie, 74, 21-25. http://dx.doi.org/10.1016/j.lwt.2016.07.022.

Pankasemsuk, T., Apichartsrangkoon, A., Worametrachanon, S., \& Techarang, J. (2016). Encapsulation of Lactobacillus casei 01 by alginate along with hi-maize starch for exposure to a simulated gut model. Food Bioscience, 16, 32-36. http://dx.doi.org/10.1016/j.fbio.2016.07.001.

Petyaev, I. M., \& Bashmakov, Y. K. (2017). Dark chocolate: opportunity for an alliance between medical science and the food industry? Frontiers in Nutrition, 4, 43. http://dx.doi.org/10.3389/fnut.2017.00043. PMid:29034240.

Possemiers, S., Marzorati, M., Verstraete, W., \& Van de Wiele, T. (2010). Bacteria and chocolate: a successful combination for probiotic delivery. International Journal of Food Microbiology, 141(1-2), 97-103. http:// dx.doi.org/10.1016/j.ijfoodmicro.2010.03.008. PMid:20452073.

Probiotics Market Outlook. (2018). Development trends, market demands, industry analysis \& forecast by 2024. Maharastra, India.

Rad, A. H., Roudbaneh, M. M., Tabrizian, V. G., Javadi, M., Harati, N., Rad, H. N., \& Kasaie, Z. (2016). Chocolates as a probiotic carrier food: a review. International Journal of Probiotics and Prebiotics, 11(1), 37-42. 
Radke, M., Picaud, J. C., Loui, A., Cambonie, G., Faas, D., Lafeber, H. N., de Groot, N., Pecquet, S. S., Steenhout, P. G., \& Hascoet, J. M. (2017). Starter formula enriched in prebiotics and probiotics ensures normal growth of infants and promotes gut health: a randomized clinical trial. Pediatric Research, 81(4), 622-631. http://dx.doi. org/10.1038/pr.2016.270. PMid:28002391.

Ranadheera, C. S., Naumovski, N., \& Ajlouni, S. (2018). Non-bovine milk products as emerging probiotic carriers: Recent developments and innovations. Current Opinion in Food Science, 22, 109-114. http://dx.doi.org/10.1016/j.cofs.2018.02.010.

Ranadheera, C., Vidanarachchi, J., Rocha, R., Cruz, A., \& Ajlouni, S. (2017). Probiotic delivery through fermentation: dairy vs. nondairy beverages. Fermentation, 3(4), 67. http://dx.doi.org/10.3390/ fermentation3040067.

Ranadheera, R. D. C. S., Baines, S. K., \& Adams, M. C. (2010). Importance of food in probiotic efficacy. Food Research International, 43(1), 1-7. http://dx.doi.org/10.1016/j.foodres.2009.09.009.

Rastall, R. A. (2013). Gluco and galacto-oligosaccharides in food: update on health effects and relevance in healthy nutrition. Current Opinion in Clinical Nutrition and Metabolic Care, 16(6), 675-678. http://dx.doi.org/10.1097/MCO.0b013e328365b5fd. PMid:24100675.

Ray, S., Raychaudhuri, U., \& Chakraborty, R. (2016). An overview of encapsulation of active compounds used in food products by drying technology. Food Bioscience, 13, 76-83. http://dx.doi.org/10.1016/j. fbio.2015.12.009.

Ritchie, M. L., \& Romanuk, T. N. (2012). A meta-analysis of probiotic efficacy for gastrointestinal diseases. PLoS One, 7(4), 34-38. http:// dx.doi.org/10.1371/journal.pone.0034938. PMid:22529959.

Roberfroid, M., Gibson, G. R., Hoyles, L., McCartney, A. L., Rastall, R., Rowland, I., Wolvers, D., Watzl, B., Szajewska, H., Stahl, B., Guarner, F., Respondek, F., Whelan, K., Coxam, V., Davicco, M. J., Léotoing, L., Wittrant, Y., Delzenne, N. M., Cani, P. D., Neyrinck, A. M., \& Meheust, A. (2010). Prebiotic effects: metabolic and health benefits. British Journal of Nutrition, 104(Suppl. 2), S1-S63. http://dx.doi. org/10.1017/S0007114510003363. PMid:20920376.

Rokka, S., \& Rantamäki, P. (2010). Protecting probiotic bacteria by microencapsulation: challenges for industrial applications. European Food Research and Technology, 231(1), 1-12. http://dx.doi.org/10.1007/ s00217-010-1246-2.

Roobab, U., Batool, Z., Manzoor, M. F., Shabbir, M. A., Khan, M. R., \& Aadil, R. M. (2020). Sources, formulations, advanced delivery and health benefits of probiotics. Current Opinion in Food Science, 32, 17-28. http://dx.doi.org/10.1016/j.cofs.2020.01.003.

Rosa, L. J. B., Esper, L. M. R., Cabral, J. D. L. G., Franco, R. M., \& Cortez, M. A. S. (2016). Viability of probiotic micro-organism Lactobacillus acidophilus in dairy chocolate dessert and its action against foodborne pathogens. Ciência Rural, 46(2), 368-374. http:// dx.doi.org/10.1590/0103-8478cr20141864.

Saarela, M., Virkajarvi, I., Nohynek, L., Vaari, A., \& Matto, J. (2006). Fibres as carriers for Lactobacillus rhamnosus during freeze-drying and storage in apple juice and chocolate-coated breakfast cereals. International Journal of Food Microbiology, 112(2), 171-178. http:// dx.doi.org/10.1016/j.ijfoodmicro.2006.05.019. PMid:16844253.

Sabir, F., Beyatli, Y., Cokmus, C., \& Onal-Darilmaz, D. (2010). Assessment of potential probiotic properties of Lactobacillus spp., Lactococcus spp., and Pediococcus spp. strains isolated from kefir. Journal of Food Science, 75(9), M568-M573. http://dx.doi.org/10.1111/j.17503841.2010.01855.x. PMid:21535612.

Sanders, M. E. (2015). Probiotics in 2015: their scope and use. Journal of Clinical Gastroenterology, 49(Suppl. 1), S2-S6. http://dx.doi. org/10.1097/MCG.0000000000000350. PMid:26447958.
Sanders, M. E., \& Younes, J. (2018). Paper incompletely describes evidence-based usage of probiotics. Gut Microbes, 9(2), 102-103. http://dx.doi.org/10.1080/19490976.2017.1393143. PMid:29053042.

Sanders, M. E., Merenstein, D., Merrifield, C. A., \& Hutkins, R. (2018). Probiotics for human use. Nutrition Bulletin, 43(3), 212-225. http:// dx.doi.org/10.1111/nbu.12334.

Sandoval-Castilla, O., Lobato-Calleros, C., García-Galindo, H., AlvarezRamírez, J., \& Vernon-Carter, E. (2010). Textural properties of alginate-pectin beads and survivability of entrapped $L b$. casei in simulated gastrointestinal conditions and in yoghurt. Food Research International, 43(1), 111-117. http://dx.doi.org/10.1016/j. foodres.2009.09.010.

Sarfraz, F., Farooq, U., Shafi, A., Hayat, Z., Akram, K., \& Rehman, H. U. (2019). Hypolipidaemic effects of synbiotic yoghurt in rabbits. International Journal of Dairy Technology, 72(4), 545-550. http:// dx.doi.org/10.1111/1471-0307.12618.

Sathyabama, S., Kumar, M. R., Devi, P. B., Vijayabharathi, R., \& Priyadharisini, V. B. (2014). Co-encapsulation of probiotics with prebiotics on alginate matrix and its effect on viability in simulated gastric environment. Lebensmittel-Wissenschaft + Technologie, 57(1), 419-425. http://dx.doi.org/10.1016/j.lwt.2013.12.024.

Shafi, A., Naeem Raja, H., Farooq, U., Akram, K., Hayat, Z., Naz, A., \& Nadeem, H. R. (2019). Antimicrobial and antidiabetic potential of synbiotic fermented milk: a functional dairy product. International Journal of Dairy Technology, 72(1), 15-22. http://dx.doi. org/10.1111/1471-0307.12555.

Shreiner, A. B., Kao, J. Y., \& Young, V. B. (2015). The gut microbiome in health and in disease. Current Opinion in Gastroenterology, 31(1), 69-75. http://dx.doi.org/10.1097/MOG.0000000000000139. PMid:25394236.

Silva, M. P., Tulini, F. L., Marinho, J. F., Mazzocato, M. C., De Martinis, E. C., Luccas, V., \& Favaro-Trindade, C. (2017). Semisweet chocolate as a vehicle for the probiotics Lactobacillus acidophilus LA3 and Bifidobacterium animalis subsp. lactis BLC1: evaluation of chocolate stability and probiotic survival under in vitro simulated gastrointestinal conditions. Lebensmittel-Wissenschaft + Technologie, 75, 640-647. http://dx.doi.org/10.1016/j.lwt.2016.10.025.

Simpson, H. L., \& Campbell, B. J. (2015). Review article: dietary fibre-microbiota interactions. Alimentary Pharmacology \& Therapeutics, 42(2), 158-179. http://dx.doi.org/10.1111/apt.13248. PMid:26011307.

Singla, V., \& Chakkaravarthi, S. (2017). Applications of prebiotics in food industry: A review. Food Science \& Technology International, 23(8), 649-667. http://dx.doi.org/10.1177/1082013217721769. PMid:28762780.

Šipailienè, A., \& Petraityte, S. (2018). Encapsulation of probiotics: proper selection of the probiotic strain and the influence of encapsulation technology and materials on the viability of encapsulated microorganisms. Probiotics and Antimicrobial Proteins, 10(1), 1-10. http://dx.doi.org/10.1007/s12602-017-9347-x. PMid:29124564.

Sirtori, C. R., Arnoldi, A., \& Cicero, A. F. (2015). Nutraceuticals for blood pressure control. Annals of Medicine, 47(6), 447-456. http:// dx.doi.org/10.3109/07853890.2015.1078905. PMid:26362125.

Slavin, J. (2013). Fiber and prebiotics: mechanisms and health benefits. Nutrients, 5(4), 1417-1435. http://dx.doi.org/10.3390/nu5041417. PMid:23609775.

Soccol, C., Prado, M., Garcia, L., Rodrigues, C., Medeiros, A., \& Soccol, V. (2014). Current developments in probiotics. Journal of Microbial \& Biochemical Technology, 7, 11-20. 
Succi, M., Tremonte, P., Pannella, G., Tipaldi, L., Cozzolino, A., Coppola, R., \& Sorrentino, E. (2017). Survival of commercial probiotic strains in dark chocolate with high cocoa and phenols content during the storage and in a static in vitro digestion model. Journal of Functional Foods, 35, 60-67. http://dx.doi.org/10.1016/j.jff.2017.05.019.

Tan, J., McKenzie, C., Potamitis, M., Thorburn, A. N., Mackay, C. R., \& Macia, L. (2014). The role of short-chain fatty acids in health and disease. Advances in Immunology, 121, 91-119. http://dx.doi. org/10.1016/B978-0-12-800100-4.00003-9. PMid:24388214.

Vandeputte, D., Falony, G., Vieira-Silva, S., Wang, J., Sailer, M., Theis, S., Verbeke, K., \& Raes, J. (2017). Prebiotic inulin-type fructans induce specific changes in the human gut microbiota. Gut Microbiota, 66(11), 1968-1974. http://dx.doi.org/10.1136/gutjnl-2016-313271. PMid:28213610.

Vasconcelos, F. M., Silva, H. L. A., Poso, S. M. V., Barroso, M. V., Lanzetti, M., Rocha, R. S., Graça, J. S., Esmerino, E. A., Freitas, M. Q., Silva, M. C., Raices, R. S. L., Granato, D., Pimentel, T. C., Sant'Ana, A. S., Cruz, A. G., \& Valença, S. S. (2019). Probiotic Prato cheese attenuates cigarette smoke-induced injuries in mice. Food Research International, 123, 697-703. http://dx.doi.org/10.1016/j. foodres.2019.06.001. PMid:31285019.

Vibhute, V., Shelke, R., Chavan, S., \& Nage, S. (2011). Effect of probiotics supplementation on the performance of lactating crossbred cows. Veterinary World, 4, 557. http://dx.doi.org/10.5455/ vetworld.2011.557-561.

Wang, Y., Wu, Y., Wang, Y., Xu, H., Mei, X., Yu, D., Wang, Y., \& Li, W. (2017). Antioxidant Properties of Probiotic Bacteria. Nutrients, 9(5), 5. http://dx.doi.org/10.3390/nu9050521. PMid:28534820.
Weichselbaum, E. (2009). Probiotics and health: a review of the evidence. Nutrition Bulletin, 34(4), 340-373. http://dx.doi.org/10.1111/j.14673010.2009.01782.x.

Wilson, B., \& Whelan, K. (2017). Prebiotic inulin-type fructans and galacto-oligosaccharides: definition, specificity, function, and application in gastrointestinal disorders. Journal of Gastroenterology and Hepatology, 32(Suppl. 1), 64-68. http://dx.doi.org/10.1111/ jgh.13700. PMid:28244671.

Yonejima, Y., Hisa, K., Kawaguchi, M., Ashitani, H., Koyama, T., Usamikrank, Y., Kishida, N., Kishino, S., \& Ogawa, J. (2015). Lactic acid bacteria-containing chocolate as a practical probiotic product with increased acid tolerance. Biocatalysis and Agricultural Biotechnology, 4(4), 773-777. http://dx.doi.org/10.1016/j.bcab.2015.09.001.

Zendeboodi, F., Khorshidian, N., Mortazavian, A. M., \& da Cruz, A. G. (2020). Probiotic: conceptualization from a new approach. Current Opinion in Food Science, 32, 103-123. http://dx.doi.org/10.1016/j. cofs.2020.03.009.

Zhang, S., Hu, H., Wang, L., Liu, F., \& Pan, S. (2018). Preparation and prebiotic potential of pectin oligosaccharides obtained from citrus peel pectin. Food Chemistry, 244, 232-237. http://dx.doi.org/10.1016/j. foodchem.2017.10.071. PMid:29120775.

Zitvogel, L., Daillere, R., Roberti, M. P., Routy, B., \& Kroemer, G. (2017). Anticancer effects of the microbiome and its products. National Review, 15(8), 465-478. http://dx.doi.org/10.1038/nrmicro.2017.44. PMid:28529325.

Zucko, J., Starcevic, A., Diminic, J., Oros, D., Mortazavian, A. M., \& Putnik, P. (2020). Probiotic-friend or foe? Current Opinion in Food Science, 32, 45-49. http://dx.doi.org/10.1016/j.cofs.2020.01.007. 